\title{
Differential Diagnosis Between Venomous (Botbrops jararaca, Serpentes, Viperidae) and "Nonvenomous" (Philodryas olfersii, Serpentes, Dipsadidae) Snakebites: Is It Always Possible?
}

\author{
Carlos R. de Medeiros, MD, $\mathrm{PhD}^{1,2,3}$; Marcelo R. Duarte, MSc ${ }^{4}$; Solange N. de Souza, BSN ${ }^{5}$ \\ ${ }^{1}$ Laboratório de Ecologia e Evolução, Instituto Butantan, São Paulo, Brazil; ${ }^{2}$ Centro de Assistência Toxicológica, Instituto da Criança do Hospital \\ das Clínicas da Faculdade de Medicina da USP, São Paulo, Brazil; ${ }^{3}$ Curso de Medicina, Centro Universitário São Camilo, São Paulo, Brazil; \\ ${ }^{4}$ Laboratório de Coleções Zoológicas, Instituto Butantan, São Paulo, Brazil; ${ }^{5}$ Hospital Vital Brazil, Instituto Butantan, São Paulo, Brazil
}

\begin{abstract}
Bites of "nonvenomous" snakes can sometimes be mistaken for the bites of venomous snakes. As an example of this confusion, this report describes confirmed bites by Philodryas olfersii and Bothrops jararaca. In the first case, a 55-y-old man with a history of controlled hypertension was bitten on his right forearm by $P$ olfersii. Physical examination revealed extensive edema, erythema, and widespread ecchymoses throughout his right upper limb. Laboratory tests indicated leukocytosis and high D-dimer levels, but normal coagulation, suggestive of a resolved recent coagulopathy. He received only supportive treatment. In the second case, a healthy 35 -y-old man was bitten by B jararaca. Although the anatomic region of the bite and the results of physical examination were similar to those in the first case, laboratory tests showed mild coagulopathy, leukocytosis, and high D-dimer levels. The patient was treated with antivenom. In both cases, the 20-min whole blood clotting test results were normal. Patients bitten by $P$ olfersii may present with local symptoms resembling $B$ jararaca envenomation. Without snake identification and the detection of venom-induced consumption coagulopathy, especially in places where the 20-min whole blood clotting test is the only clotting test available, it is almost impossible to establish an accurate and safe differential diagnosis. In this context, the best alternative is to take the risk of prescribing antivenom for a possible $P$ olfersii bite rather than failing to do so for a real Bothrops bite. Late treatment for Bothrops bite can result in severe complications and sequelae.
\end{abstract}

Keywords: non-front-fanged colubroids, nonvenomous snake, antivenom

\section{Introduction}

Non-front-fanged colubroid (NFFC) snakes comprise approximately two-thirds of the described species of advanced snakes. ${ }^{1}$ However, the medical significance of the majority of the NFFC taxa is unknown, ${ }^{1}$ and their bites can sometimes be mistaken for the bites of front-fanged venomous snakes. ${ }^{2}$ Here we describe the cases of 2 confirmed bites, 1 by Philodryas olfersii (Lichtenstein, 1823) (Figure 1A), an NFFC snake, and the other by Bothrops jararaca (Wied, 1824) (Figure 2A), a pit viper, as examples of how this confusion can occur. Both patients

Corresponding author: Carlos R. de Medeiros, MD, PhD, Rua Guilhermina, 313, Vila Romero, São Paulo, SP, Brazil; e-mail: carlos.medeiros@butantan.gov.br.

Submitted for publication April 2021.

Accepted for publication July 2021 were admitted to the Hospital Vital Brazil (HVB), Instituto Butantan, São Paulo, Brazil, a hospital specializing in the care of patients involved in accidents caused by venomous animals. In both cases, the snakes were brought to the hospital by the patients and identified by technicians or researchers at the Laboratório de Coleções Zoológicas. The identifications were made from voucher specimens that were housed in the herpetologic collection of Alphonse Richard Hoge, Instituto Butantan, São Paulo, Brazil.

\section{Details of Cases}

\section{CASE 1}

A 55-y-old man with a history of controlled hypertension was bitten on the dorsal surface of the distal third of his right forearm while trying to capture an adult $P$ olfersii 


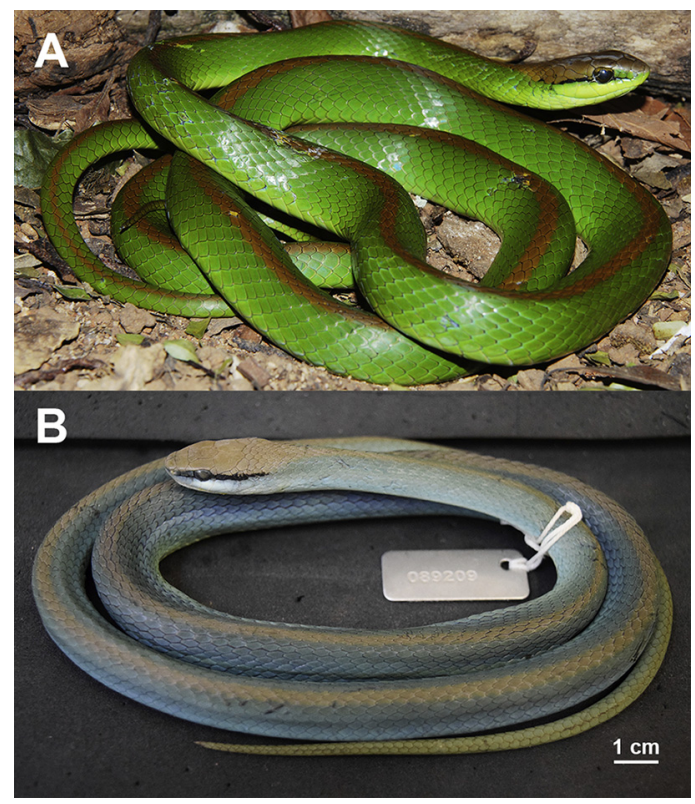

Figure 1. (A) Philodryas olfersii (Lichtenstein, 1823), a nonfrontfanged colubroid snake; living specimen photographed in the municipality of Jundiaí $\left(23^{\circ} 11^{\prime} 11^{\prime \prime} \mathrm{S}, 46^{\circ} 53^{\prime} 03^{\prime \prime} \mathrm{W}\right)$, about $38 \mathrm{~km}$ from São Paulo. (B) Philodryas olfersii (Instituto Butantan, São Paulo, Brazil number 89209 ) was brought by the Case 1 patient. Adult female, total length $87.5 \mathrm{~cm}$, mass $80 \mathrm{~g}$, origin Cabreúva (23⒈ $\left.8^{\prime 2} 7^{\prime \prime} \mathrm{S}, 47^{\circ} 7^{\prime} 59^{\prime \prime} \mathrm{W}\right)$, about 87 km from São Paulo. (Photos by Marcelo Ribeiro Duarte).

(female, total length $87.5 \mathrm{~cm}$, mass $80 \mathrm{~g}$ ) (Figure 1B). The snake was in the backyard of his house, located in a rural area in the municipality of Cabreúva $\left(23^{\circ} 18^{\prime} 27^{\prime \prime} \mathrm{S}\right.$, $47^{\circ} 7^{\prime} 59^{\prime \prime} \mathrm{W}$ ), about $87 \mathrm{~km}$ from the city of São Paulo. Upon arrival at the HVB, $10 \mathrm{~h}$ post-bite, the following data were recorded: blood pressure $155 / 87 \mathrm{~mm} \mathrm{Hg}$, heart rate 111 beats $\cdot \mathrm{min}^{-1}$, axillar temperature $35.8^{\circ} \mathrm{C}$, and oxygen saturation $95 \%$ on room air. The patient reported pain extending from the bite site to the underarm. Physical examination revealed the presence of semicircular bite marks and severe edema, erythema, and widespread ecchymoses throughout his right upper limb (Figure 3A-C). He denied having used a tourniquet.

Laboratory test results on admission are presented in Table 1. The fibrinogen level, prothrombin time, international normalized ratio (INR), activated partial thromboplastin time, 20-min whole blood clotting test (WBCT20), and platelet count were all within the normal ranges. However, leukocytosis and increased levels of urea, creatinine, D-dimer, and C-reactive protein (CRP) were observed. All of the initial test results normalized spontaneously by the second day of hospitalization, except for the D-dimer level, which continued to increase, and a subsequent increase in the creatinine kinase level. The patient was discharged after treatment with anti-inflammatory drugs and corticosteroids. Within $2 \mathrm{~d}$, he no longer had any pain, and swelling showed significant improvement. He recovered completely after $3 \mathrm{wk}$.

\section{CASE 2}

A healthy 35-y-old man presented with a bite on the dorsal surface of the distal third of his right forearm from an adult $B$ jararaca (female, total length $92.6 \mathrm{~cm}$ with mutilated tail, mass $254 \mathrm{~g}$ ) (Figure 2B) sustained while working in his vegetable garden. His home was located in a rural area in the municipality of Itapecerica da Serra ( $\left.23^{\circ} 43^{\prime} 03^{\prime \prime} \mathrm{S}, 46^{\circ} 50^{\prime} 58^{\prime \prime} \mathrm{W}\right)$, about $30 \mathrm{~km}$ from the city of São Paulo. Two hours after the snakebite, he was admitted to the HVB with blood pressure $149 / 76 \mathrm{~mm} \mathrm{Hg}$, heart rate 63 beats $\cdot \mathrm{min}^{-1}$, axillary temperature $36.2^{\circ} \mathrm{C}$, and oxygen saturation $98 \%$ on room air. He reported pain and swelling, which quickly progressed from the bite site toward his hand and elbow. On physical examination, he displayed excoriations at the bite site and extensive edema, erythema, and sparse ecchymosis throughout his right upper limb (Figure 3D-F). Laboratory tests on admission (Table 1) showed leukocytosis, coagulopathy with fibrinogen consumption, and thrombocytopenia, despite the normal WBCT20.

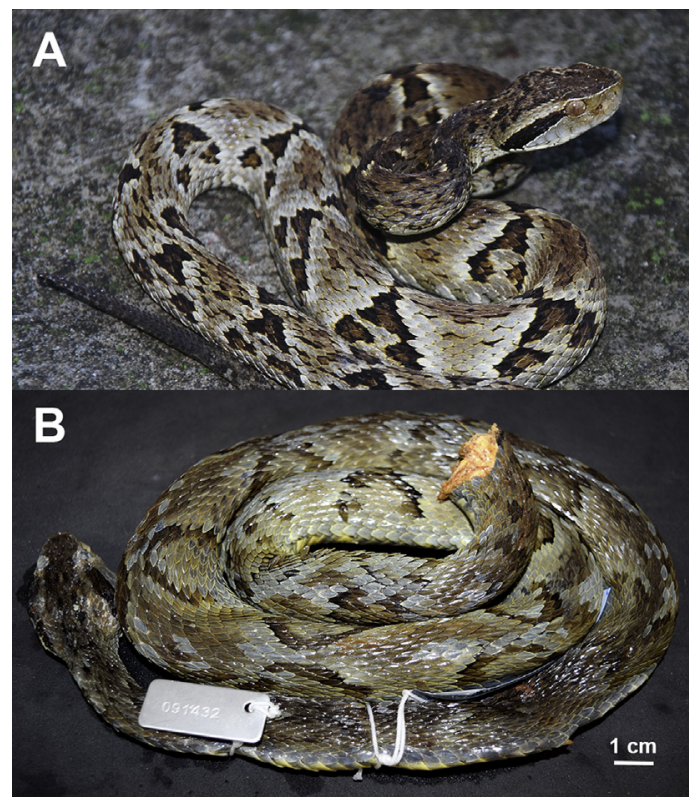

Figure 2. (A) Bothrops jararaca (Wied, 1824), a pit viper; living specimen photographed in the municipality of Cotia $\left(23^{\circ} 00^{\prime} 25\right.$ 'S, $47^{\circ} 08^{\prime} 04^{\prime \prime W}$ ), about $38 \mathrm{~km}$ from São Paulo. (B) Bothrops jararaca (Instituto Butantan, São Paulo, Brazil number 91432) brought by the Case 2 patient. Adult female, total length $92.6 \mathrm{~cm}$ (mutilated tail), mass $254 \mathrm{~g}$, origin Itapecerica da Serra $\left(23^{\circ} 43^{\prime} 03^{\prime \prime} \mathrm{S}, 46^{\circ} 50^{\prime} 58^{\prime \prime} \mathrm{W}\right)$, about $30 \mathrm{~km}$ from São Paulo. (Photos by Marcelo Ribeiro Duarte). 

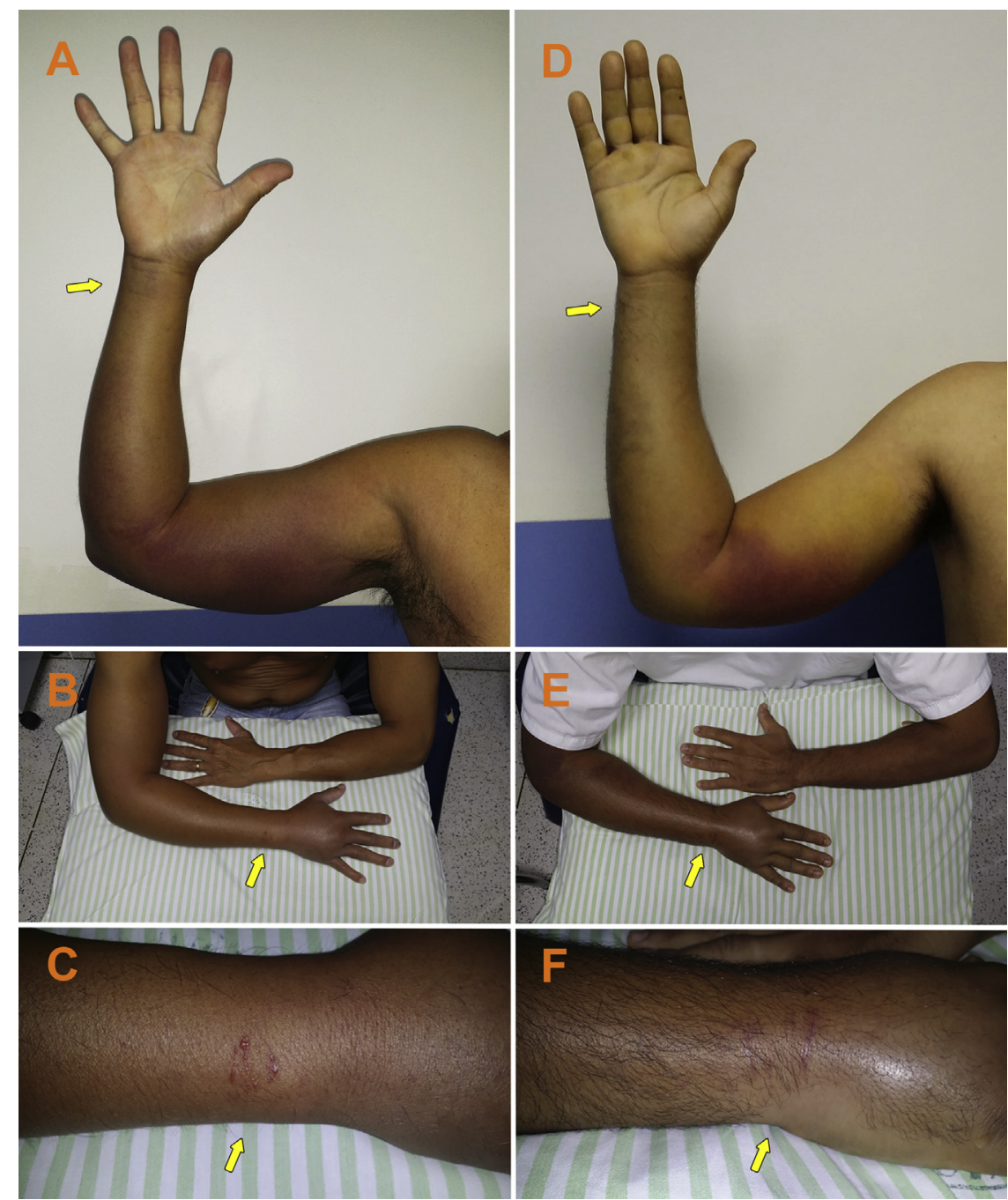

Figure 3. (A, B) Patient bitten by Philodryas olfersii on the dorsal surface of the distal third of his right forearm. Physical examination revealed severe edema, erythema, and widespread ecchymoses throughout his right upper limb. (C) Bite site detail showing semicircular bite marks. (D, E) Patient bitten by Bothrops jararaca on the dorsal surface of the distal third of his right forearm. Physical examination revealed severe edema, erythema, and widespread ecchymoses throughout his right upper limb. (F) Bite site detail showing excoriations caused by snake's dentition. (Photos by Carlos Roberto de Medeiros).

Eight vials of anti-Bothrops antivenom (BAV) were diluted and administered intravenously. BAV is a polyvalent antivenom containing equine-derived antibody fragments $\left[\left(\mathrm{F}\left(\mathrm{ab}^{\prime}\right) 2\right]\right.$ against the venom of 5 Bothrops species (B jararaca, B neuwiedi, B alternatus, B moojeni, and $B$ jararacussu), manufactured by Instituto Butantan, São Paulo, Brazil. According to the manufacturer, $1 \mathrm{~mL}$ neutralizes the lethality of $5 \mathrm{mg}$ standard $B$ jararaca venom. The patient's INR and fibrinogen values reached normal limits $19 \mathrm{~h}$ after antivenom administration. On Day 2 after the bite, the patient was afebrile, with erythema and increased temperature at the bite site and elevated CRP. He was treated with chloramphenicol owing to a secondary infection at the bite site. No microbial culture was performed. He was discharged after $4 \mathrm{~d}$ with a normal thrombocyte count, but with edema that persisted for approximately $2 \mathrm{wk}$.

\section{Discussion}

Snakebite victims often bring snakes to the hospital or take pictures of the snake. When this occurs, provided that correct identification by an experienced professional takes place, a differential diagnosis is facilitated. Otherwise, because local clinical presentations may be 
Table 1. Laboratory test results of patients bitten by Philodryas olfersii (Case 1) and Bothrops jararaca (Case 2)

\begin{tabular}{|c|c|c|c|c|c|c|c|c|}
\hline \multirow[t]{2}{*}{ Test } & \multicolumn{3}{|c|}{$\begin{array}{c}\text { Case } 1 \\
\text { Philodryas olfersii bite }\end{array}$} & \multicolumn{4}{|c|}{$\begin{array}{c}\text { Case } 2 \\
\text { Bothops jararaca bite }\end{array}$} & \multirow[t]{2}{*}{$\begin{array}{l}\text { Reference } \\
\text { range }\end{array}$} \\
\hline & Admission & $\begin{array}{l}\text { First } \\
\text { day }\end{array}$ & $\begin{array}{l}\text { Second } \\
\text { day }\end{array}$ & Admission & $\begin{array}{l}\text { First } \\
\text { day }\end{array}$ & $\begin{array}{l}\text { Second } \\
\text { day }\end{array}$ & $\begin{array}{l}\text { Fourth } \\
\text { day }\end{array}$ & \\
\hline $\begin{array}{l}\text { Hemoglobin } \\
\left(\mathrm{mg} \cdot \mathrm{dL}^{-1}\right)\end{array}$ & 16.6 & 14.1 & 13.5 & 15.6 & 14.8 & 13.6 & 13.4 & $13.5-17.5$ \\
\hline $\begin{array}{l}\text { Leukocyte } \\
\qquad\left(\cdot \mu \mathrm{L}^{-1}\right)\end{array}$ & 17,450 & 13,100 & 11,290 & 18,690 & 13,230 & 11,200 & 6000 & $\begin{array}{l}4500- \\
11,000\end{array}$ \\
\hline $\begin{array}{l}\text { Platelets } \\
\qquad\left(\cdot \mu \mathrm{L}^{-1}\right)\end{array}$ & 238,000 & 204,000 & 206,000 & 15,000 & 72,000 & 83,000 & 207,000 & $\begin{array}{r}150,000- \\
400,000\end{array}$ \\
\hline $\begin{array}{l}\text { Sodium } \\
\qquad\left(\mathrm{mEq} \cdot \mathrm{L}^{-1}\right)\end{array}$ & - & 140 & 141 & 142 & 142 & 140 & - & $136-145$ \\
\hline $\begin{array}{l}\text { Potassium } \\
\qquad\left(\mathrm{mEq} \cdot \mathrm{L}^{-1}\right)\end{array}$ & - & 4.6 & 3.7 & 3.2 & 4.3 & 4.7 & - & $3.5-4.5$ \\
\hline $\begin{array}{l}\text { Creatinine } \\
\qquad\left(\mathrm{mg} \cdot \mathrm{dL}^{-1}\right)\end{array}$ & 1.37 & 1.11 & 1.02 & 0.95 & 0.92 & 0.92 & - & $0.70-1.20$ \\
\hline Urea $\left(\mathrm{mg} \cdot \mathrm{dL}^{-1}\right)$ & 65 & 52 & 43 & 25 & 20 & 19 & - & $17-49$ \\
\hline $\operatorname{AST}\left(\mathrm{U} \cdot \mathrm{L}^{-1}\right)$ & 21 & - & 22 & 22 & - & 26 & 37 & $\leq 40$ \\
\hline $\operatorname{ALT}\left(\mathrm{U} \cdot \mathrm{L}^{-1}\right)$ & 39 & - & 33 & 24 & - & 21 & 45 & $\leq 41$ \\
\hline $\mathrm{LDH}\left(\mathrm{IU} \cdot \mathrm{L}^{-1}\right)$ & - & 166 & 216 & 199 & 146 & 284 & 154 & $\leq 250$ \\
\hline $\begin{array}{l}\text { Creatinine } \\
\text { kinase } \\
\left(\mathrm{IU} \cdot \mathrm{L}^{-1}\right)\end{array}$ & 149 & - & 213 & 145 & 132 & 245 & 120 & $\leq 190$ \\
\hline $\begin{array}{l}\mathrm{C} \text { reactive } \\
\text { protein } \\
\left(\mathrm{mg} \cdot \mathrm{dL}^{-1}\right)\end{array}$ & 1.4 & 1.4 & 0.5 & $<0.5$ & 2.1 & 5.0 & 4.9 & $<0.5$ \\
\hline $\begin{array}{l}\text { Fibrinogen } \\
\qquad\left(\mathrm{mg} \cdot \mathrm{dL}^{-1}\right)\end{array}$ & 278 & 284 & 253 & 103 & 255 & 413 & - & $238-498$ \\
\hline $\begin{array}{l}\text { D-dimer } \\
\quad\left(\mathrm{mg} \cdot \mathrm{L}^{-1}\right)\end{array}$ & 1.943 & 2.683 & 2.740 & 7.530 & - & 1.975 & - & $<0.500$ \\
\hline PT (s) & 13.4 & - & 12.5 & 17.2 & 15.7 & 14.8 & - & $11.5-14.5$ \\
\hline aPTT (s) & 25.7 & - & 25.2 & 30.8 & 29.5 & 29.3 & - & $25.4-36.9$ \\
\hline INR & 1.00 & - & 1.00 & 1.32 & 1.18 & 1.10 & - & $0.80-1.20$ \\
\hline WBCT20 (s) & Coagulable & - & - & Coagulable & Coagulable & - & - & Coagulable \\
\hline
\end{tabular}

ALT, alanine aminotransferase; aPTT, activated partial thromboplastin time; AST, aspartate aminotransferase; INR, international normalized ratio; LDH, lactate dehydrogenase; PT, prothrombin time; WBCT20, 20-minute whole blood clotting test.

similar, a differential diagnosis between venomous and "nonvenomous" snakebites can be difficult. ${ }^{2}$

Figure 3 shows that in both cases, the patients were bitten in the same anatomic region and had edema throughout the upper limb, associated with erythema and widespread ecchymoses. These symptoms are common in bites from Bothrops $\mathrm{spp}^{3,4}$ and have been frequently reported in bites from $P$ olfersii. ${ }^{5-7}$ In Case 1 , the bite marks were semicircular and suggestive of a "nonvenomous" snakebite (Figure 3C). In Case 2, the patient displayed excoriations at the bite site rather than the classic 2 perforations of a bite from a pit viper (Figure 3F). Although some authors have considered examination of the bite marks useful in the differential diagnosis between venomous and "nonvenomous" snakebites, its isolated use cannot be considered reliable owing to its low specificity. ${ }^{8}$ In a recent study, semicircular bite marks were observed in less than a quarter of 141 cases of bites by $P$ olfersii. ${ }^{5}$

Regarding the laboratory tests, in Case 1 , the patient did not present with venom-induced consumption coagulopathy (VICC), only leukocytosis and high CRP and D-dimer levels, without consumption of fibrinogen and platelets or changes in prothrombin time, INR, or activated partial thromboplastin time. In the following days, D-dimer levels continued to increase (Table 1), accompanied only by a small increase in creatinine kinase, with no other changes suggestive of VICC. It is possible that these laboratory findings may have been due to extensive local inflammation. It has been shown that the principal effects of $P$ olfersii venom in mice are local 
edema, inflammatory cell infiltration, and myonecrosis, probably mediated by metalloproteinases, serine proteinases, cysteine-rich secretory proteins, and other components present in $P$ olfersii venom. ${ }^{9}$ The patient was also seen only $10 \mathrm{~h}$ after the bite, which does not allow us to rule out the possibility of transient coagulopathy. However, no clinically documented or confirmed coagulopathy from envenomation by $P$ olfersii has been reported in the literature, ${ }^{5}$ and the continuous elevation of the D-dimer levels without fibrinogen or platelet consumption observed in subsequent days does not support this hypothesis. Nevertheless, further studies are needed to clarify this issue. However, the patient also showed acute kidney injury, which resolved after hydration. Because there was no substantial increase in lactate dehydrogenase and thrombocytopenia, it is unlikely to have been due to microangiopathic hemolytic anemia previously described in envenomation by other snakes. ${ }^{10}$ The drop in hematocrit may have been attributed to hemodilution caused by hydration and, at least in part, to extensive ecchymosis.

Bothrops spp are the most common cause of human snakebites in South and Central America. Bothrops envenomation can manifest with local inflammatory signs and hemostatic disorders. ${ }^{3,4}$ Common signs and symptoms include pain, swelling, and bleeding, occurring within the first $6 \mathrm{~h}$ after envenomation. ${ }^{3}$ In Brazil, Bothrops envenomation severity is classified as mild, moderate, or severe and treated with 3 to 4,6 to 8 , or 12 vials of BAV, respectively. Mild cases are defined as the presence of mild local signs, such as edema. Moderate cases include regional edema, and severe cases include swelling around the full length of the affected limb, acute kidney injury, shock, and/or severe hemorrhage. ${ }^{3}$ These definitions do not take into account the presence or absence of coagulopathy. ${ }^{3}$ In Case 2 , the patient was admitted $2 \mathrm{~h}$ after the bite, with extensive edema, erythema, and sparse ecchymosis throughout his right upper limb. In addition to leukocytosis and elevated D-dimer levels, he presented with active VICC as shown by the consumption of fibrinogen, as well as thrombocytopenia. WBCT20 coagulability was not sensitive enough to detect slight changes in coagulation. ${ }^{10}$ These are the classical alterations present in patients bitten by Bothrops spp in Latin America,, which facilitated diagnosis in association with identification of the snake. VICC and thrombocytopenia regressed after the use of the antivenom (Table 1), and the secondary infection was effectively treated with antibiotics.

Differentiating between the 2 types of envenomation is extremely important because treatment involves the use of antivenom. Misuse of antivenom, despite identification of the snake, has been observed in cases of bites by $P$ olfersii reported in the literature. ${ }^{2}$ Although $P$ olfersii venom exhibits immunologic cross-reactivities to polyvalent
BAV,${ }^{11}$ its use in the treatment of $P$ olfersii bites does not seem to be justified because no controlled clinical study has used the antivenom in the treatment of these patients. Thus, the problem is not restricted to the identification of snakes, but includes misinformation about the differences between the medical risks posed by front-fanged venomous snakes and NFFC snakes, thus contributing to the inappropriate treatment of these bites. ${ }^{2,5}$

In many snakebite cases, the snake responsible remains unidentified, which frequently results in difficulties in deciding which antivenom to administer. However, the diagnosis of a venomous snakebite or determination of the snake possibly responsible for envenomation can be made using clinical criteria. ${ }^{12}$ Clinical diagnosis depends on the recognition of envenomation symptoms observed in the patient. Localized symptoms of swelling, ecchymosis, blistering, and necrosis, or systemic symptoms such as hemorrhage, incoagulable blood, hypovolemic shock, neurotoxic signs, and rhabdomyolysis, may be observed depending on the genus of the envenoming snake (in Brazil the genera Bothrops, Crotalus, Lachesis, Leptomicrurus, or Micrurus). ${ }^{3,12}$ In Case 2, the presence of coagulopathy and the correct identification of the snake ( $B$ jararaca) allowed for safe prescription of antivenom. However, because both factors are not always present, despite the presence of local symptoms, an alternative is the use of immunologic tests, ${ }^{12}$ which are unfortunately not available in Brazil. Furthermore, in Case 2, the WBCT20 was not sensitive enough to detect mild VICC, which can be a problem in low-income settings where most snakebites occur and where bedside clotting tests, such as the WBCT20, play a major role in diagnosing coagulopathy. ${ }^{10}$ In Case 2 , if we could not identify the snake and only used the WBCT20 for the diagnosis of VICC, it would have been dangerous to wait for the progression of symptoms or the diagnosis of coagulopathy; studies have shown that delayed treatment increases the risk of serious complications, such as necrosis and amputation. ${ }^{3}$

In the absence of snake identification, differentiating between bites by $P$ olfersii and Bothrops spp may be especially difficult in some regions of Brazil, where there are other crotaline species that, although relatively rare, can cause coagulopathy and local symptomology similar to envenomation from Bothrops spp, Lachesis muta (the only Bushmaster species in the Amazon rainforest and Atlantic Forest of Northeast and Southeast Brazil), ${ }^{13}$ and Crotalus durrissus ruruima (present in the state of Roraima in Northern Brazil). ${ }^{14}$ Envenomation from other subspecies of Brazilian Crotalus durrissus (species cascavella, collilineatus, dryinas, marajoensis, and terrificus) typically results in localized paresthesia at the bite site, with edema and erythema being rare or discrete, 
confined to the bite site with ascending edema infrequently observed. ${ }^{14}$ Primary systemic symptoms after envenomation by these subspecies are neurotoxicity and myotoxicity (myasthenic facies, prostration, drowsiness, myalgia, hematuria, and kidney failure). ${ }^{14}$

\section{Conclusion}

Even if the health professional knows the difference in the medical risks posed by these 2 species, patients bitten by $P$ olfersii may present with local symptoms resembling mild-to-moderate $B$ jararaca envenomation. This situation can lead to a misdiagnosis in the absence of precise identification of the snake or sensitive tests to detect mild VCCI. The unavailability of immunologic tests worsens the situation. This combination of factors makes it almost impossible to establish a safe differential diagnosis of Bothrops spp envenomation and discard the need for antivenom. In this context, a reasonable alternative is to take the risk of prescribing antivenom for a possible $P$ olfersii bite, because failure to do so for a real Bothrops bite can result in severe complications and sequelae if treatment is delayed.

Acknowledgments: The authors thank the nursing staff, especially Edna Maria P. O. Conceição, José R. Soares, Nasci A. Jesus, Lourdes A. Cavalheiro, Neide J. Santos, Paula R. Amaral, Sueli M. Rodrigues, and Valquiria O. U. Pereira, who helped in the collection of laboratory tests, separation of medical records, and patient positioning to take photographs. We are also grateful to the nurse Oséas Perazzoli (in memoriam) for his support in treating patients.

Author Contributions: Clinical examination of patients and review of medical records (CRM, SNS); data acquisition (MRD); drafting of the manuscript (CRM); critical revision of the manuscript (MRD, SNS); approval of final manuscript (CRM, MRD, SNS).

Financial/Material Support: None.

Disclosures: None.

\section{References}

1. Weinstein S, White J, Westerström A, Warrell DA. Anecdote vs. substantiated fact: the problem of unverified reports in the toxinological and herpetological literature describing non-front-fanged colubroid ("colubrid") snakebites. Herpet Rev. 2013;44(1):23-9.

2. Weinstein SA, Warrell DA, White J, Keyler DE. Medically significant bites by "Colubrid" snakes. In: Weinstein SA, Warrell DA, White J, Keyler DE, eds. Venomous Bites from Non-venomous Snakes: a Critical Analysis of Risk and Management of "Colubrid" Snake Bites. London: Elsevier Science; 2011:142-52.
3. Nicoleti AF, de Medeiros CR, Duarte MR, França FOS. Comparison of Bothropoides jararaca bites with and without envenoming treated at the Vital Brazil Hospital of the Butantan Institute, State of São Paulo, Brazil. Rev Soc Bras Med Trop. 2010;43(6):657-61.

4. Mamede CCN, de Sousa Simamoto BB, da Cunha Pereira DF, de Oliveira Costa J, Ribeiro MSM, de Oliveira F. Edema, hyperalgesia and myonecrosis induced by Brazilian bothropic venoms: overview of the last decade. Toxicon. 2020;187:10-8.

5. Castro FC, de Souza SN, de Almeida-Santos SM, Miyaji KT, de Medeiros CR. Bites by Philodryas olfersii (Lichtenstein, 1823) and Philodryas aestiva (Duméril, Bibron and Duméril, 1854) (serpentes, dipsadidae) in São Paulo, Brazil: a retrospective observational study of 155 cases. Toxicon. 2021;197:55-64.

6. Correia JM, Neto PLS, Pinho MSS, da Silva JA, Amorim MLP, Escobar JAC. Poisoning due to Philodryas olfersii (Lichtenstein, 1823) attended at Restauração Hospital in Recife, State of Pernambuco, Brazil: case report. Rev Soc Bras Med Trop. 2010;43(3):336-8.

7. Barbosa VN, da Silva Amaral JM, Alves AAA, França FGR. A new case of envenomation by neotropical opisthoglyphous snake Philodryas olfersii (Lichtenstein, 1823 ) in Recife, State of Pernambuco, Brazil. Rev Soc Bras Med Trop. 2020;53:e20200151.

8. Nishioka SA, Silveira PV, Bauab FA. Bite marks are useful for the differential diagnosis of snakebite in Brazil. Wilderness Environ Med. 1995;6(2):183-8.

9. Oliveira JS, Sant'Anna LB, Oliveira Junior MC, Souza PRM, Souza ASA, Ribeiro W, et al. Local and hematological alterations induced by Philodryas olfersii snake venom in mice. Toxicon. 2017;132:9-17.

10. Wedasingha S, Isbister G, Silva A. Bedside coagulation tests in diagnosing venom-induced consumption coagulopathy in snakebite. Toxins (Basel). 2020;12(9):583.

11. Rocha MMT, Paixão-Cavalcante D, Tambourgi DV, Furtado MFD. Duvernoy's gland secretion of Philodryas olfersii and Philodryas patagoniensis (Colubridae): neutralization of local and systemic effects by commercial bothropic antivenom (Bothrops genus). Toxicon. 2006;47(1):95-103.

12. Theakston RDG, Laing GD. Diagnosis of snakebite and the importance of immunological tests in venom research. Toxins (Basel). 2014;6(5):1667-95.

13. Lima PHS, Haddad Junior V. A snakebite caused by a bushmaster (Lachesis muta): report of a confirmed case in State of Pernambuco, Brazil. Rev Soc Bras Med Trop. 2015;48(5):636-7.

14. Asato MS, Carbonell RCC, Martins AG, Moraes CM, Chávez-Olórtegui C, Gadelha MAC, et al. Envenoming by the rattlesnake Crotalus durissus ruruima in the state of roraima, Brazil. Toxicon X. 2020;8:100061. 